Miao, J. T. and Phelps, N. A. (2019) The intrapreneurial state: Singapore's emergence in the smart and sustainable urban solutions field. Territory, Politics, Governance, 7(3), pp. 316-335. (doi: $10.1080 / 21622671.2018 .1467787$ )

There may be differences between this version and the published version. You are advised to consult the publisher's version if you wish to cite from it.

http://eprints.gla.ac.uk/160977/

Deposited on: 9 May 2018

Enlighten - Research publications by members of the University of Glasgow http://eprints.gla.ac.uk 
The Intrapreneurial State: Singapore's Emergence in the Smart and Sustainable Urban Solutions Field

Julie Tian Miao

Urban Studies, University of Glasgow, 29 Bute Gardens, Glasgow, G12, 8RS

Email: tian.miao@glasgow.ac.uk

Nicholas A. Phelps

Bartlett School of Planning, University College London, Central House

14 Upper Woburn Place, London, WC1H ONN

Email: n.phelps@ucl.ac.uk 


\section{The Intrapreneurial State: Singapore's Emergence in the Smart and Sustainable Urban Solutions Field}

The East Asian developmental state model and the Anglo-American entrepreneurial state model profile varied ways in which the state continues to intervene in economic development. These models are developed by different disciplines and against diverse contexts to capture extrasocietal state responses to neoliberalism and globalisation but leave the intrasocietal pre-conditions for state evolution little explored. We elaborate the concept of state intrapreneurialism as one way of understanding the interrelationship between economic and state transformation - one ingredient of the intrasocietal preconditions underpinning the responses to extrasocietal changes emphasised in the post-developmental state literature. Drawing on the case of Singapore's emergence in the field of smart/sustainable urban solutions, the subsidiary contributions of this paper are to suggest intrapreneurship as a specific and enduring advantage within the developmental state model, especially when set against its limitations signalled in the post-developmental state literature.

Keywords: intrapreneurialism, developmental state, entrepreneurial state, Singapore, smart and sustainable urban solutions

\section{Introduction}

Processes of neoliberalisation have called forth theories which emphasize the entrepreneurialism of states (Eisinger, 1988; Mazzucato, 2013) and the emergence of a distinctly post-developmental state (Yeung, 2016). Yet accounts of both the postdevelopmental and entrepreneurial state have largely focused on the extrasocietal origins of state responses to neoliberalisation, decentralisation and globalisation, but fail to appreciate the extent, nature and sources of state intrapreneurship as one crucial intrasocietal precondition for the state to deal with external challenges.

Few good definitions of intrapreneurialism exist and those that do are found in connection to the private sector. Adapting these definitions, state intrapreneurship can be defined as the latent or actually existing entrepreneurialism apparent within public sector 
bureaucracies. State intrapreneurialism is not new but we suggest that a focus upon it offers an important theoretical advance since: its sources and significance have not been clearly specified to date; it remains a largely overlooked feature in the extant literature on varieties of the state; it is one vital ingredient in the transformation from one 'state of stateness' (Nettl, 1968) to another. We argue that the concept of state intrapreneurship provides an additional organising framework with which to address the neglected positive role of states in effecting structural economic transformation (Bardhan, 2016) and further specify the causes of transition from developmental to post-developmental states in Asia. We believe this paper complements the extant literature - which tends to emphasise the extrasocietal sources of the post-developmental state transition - with a discussion of its neglected intrasocietal counterpart. We focus on the example of Singapore, bearing in mind that Singapore is unique among its Asian neighbours (Olds and Yeung 2004).

In what follows we first review the literature on developmental and entrepreneurial states, which leads us to focus on intrapreneurialism as partially framed at the junctions between the two as a mechanism of transformation from within the state. We then describe the methods used in connection with a case study of Singapore. Section four presents the case study, focused on the role of the state in stimulating its smart/sustainable urban solutions sector. Section five summarises the key arguments and their implications for future research.

\section{After the developmental state: intrapreneurialism and transformation}

In this section we recount facets of the developmental, entrepreneurial and postdevelopmental state models, and how they separately deal with the states' intrasocietal dynamics and extrasocietal reactions. Then we outline states' intrasocietal adjustments in terms of 'state intrapreneurialism' as a framework for analysis. 


\section{Four aspects of the developmental state}

The developmental state model dates to Johnson (1982) in his study of the post-war industrialisation process of Japan. The label is 'a shorthand for the seamless web of political, bureaucratic, and moneyed influences that structures economic life' (Woo-Cummings 1999, p.1). Notwithstanding the lack of a unified definition, we extract four common features of the developmental state from the literature (represented in the horizontal sequence of 'leadershipindustrial priorities-action power-outcomes' in figure 1) and highlight the feedback mechanism that joins them.

Priority setting is the state's proactive role in strategically predicting and supporting next generation industries. This function is not confined to 'following the market', but involves actively forecasting and preparing the pre-conditions (Johnson, 1982). Wade (1990, p.334) compared the government interventions in Taiwan, South Korea and Japan concluding that they had not so much picked winners as made them. That 'the potency of a developmental state lies in its capacity and capability to anticipate and respond to economic change' (Low 2001, p.414) is revealing of the transformative capabilities implied in priority setting.

Leadership signals capabilities that exceed bureaucratic management and embrace the intrasocietal-facing skills of coordinating the competing interests of different social classes and designing appropriate institutional infrastructures. The potential connections between the leadership of states and enterprises have since been developed in discussions of 'bureaucratic embedded autonomy' (Evans, 1995): a term used to describe the close relationship between an elite bureaucracy and government-linked companies (GLCs), and between economic goals and social welfare ensuring consensus is reached across different walks of life. South Korea was successful in achieving this embedded autonomy (Evans, 1995) as were Singapore and Hong Kong (Yu 1997). This elite-based, (semi-)closed leadership structure of high stateness 
(Öniş 1991, p.114) has, however, been transformed with increasing social democracy (Chu 2009) after the Asian financial crisis. Decision making by an elite few is increasingly replaced by a networked governance structure. Larson and Park (2014) describe the transformation of South Korea's developmentalism toward a 'network state' featuring rising power among private groups in directing the national ICT industry. Democracy and government accountability have received more attention partially in response to the neoliberalism of institutions such as the World Bank, the rise of civil awareness (Robinson and White 1998), and the weakening of bureaucracies' directedness in favour of steering (Stubbs 2009).

Action power is achieved through sustained bureaucratic power and the proactive roles played by the 'pilot agencies' of the state, such as the Ministry of International Trade and Industry, which was described as 'the greatest concentration of brainpower in Japan' (Johnson 1982, pp.26-8). Even in the US, the Advanced Research Projects Agency, financed centrally by the Pentagon, had pioneered innovations in information processing, computing and the internet, in which the US has enjoyed a leading position (Block 2008; Mazzucato 2013). Sufficient resources are the preconditions for high stateness and its implementation power according to Tilly (1990), which include fiscal power, legitimacy, skilled manpower, and organizational and technical knowledge. National pilot agencies are well-equipped with these resources (Low 2005), and the state is generally in tight control of tax and finances (Gray et al. 2007), all of which help to enhance the action power of the state.

Developmental states are outcome driven. High economic growth rates and low unemployment provide the resources and capital to reinvest in national priorities, as well as the legitimacy and persuasive power enjoyed by the state. Chua (2011, pp.31-2) described how the economic success of Singapore had become part of the national identity and a guarantee for hard work, reliability and efficiency that its citizens and companies could 
leverage on when venturing abroad. Yu (1997) identified that export performance was used by many developmental states as the most important indicator of progress. Exports, or other indicators of international competitiveness, provided a 'known principle' by which governments adjusted to unforeseen contingencies (Wade 1990).

The prominence given to international trading surplus and 'reputation' by developmental states signals the irreducible nature of the state in international relations, an extrasocietal function that 'no amount of conceptual restructuring can dissolve' (Nettl, 1968, p.559). However it also may divert analytical attention away from important transformations taking place with regard to the intrasocietal functions of the state. Indeed, reputation is very much a product of the policy credibility that states are able to generate intrasocietally and seek to extend extrasocietally - by means that are varied in their territoriality as we describe below. Here Singapore is doubly and perhaps uniquely positioned - its attention to the outputs of policy reflecting the history of an economy constructed almost entirely from international flows of labour and capital and one remaining sensitive to the disciplines of high levels of international economic integration (Bardhan, 2016, p.874).

\section{The entrepreneurial state}

The entrepreneurial state model (Duvall and Freeman 1983) has been referred to widely and in diverse ways in the West to capture the response of states to processes of globalisation and neoliberalism. ${ }^{1}$ Initially, Freeman (1982, p.90) had defined state entrepreneurship narrowly as 'a policy through which productive enterprises are owned as public agencies but operated in accordance with standard business criteria' Nowadays a broader conception of state entrepreneurship analogous to public-private partnerships is apparent with Ebner (1991, p.370) reformulated it as 'specific institutional modes of coordination between the public and

\footnotetext{
${ }^{1}$ The entrepreneurial state literature is heterogeneous in its philosophical underpinnings and in its reference to national and local scales. It is important to bear this limitation in mind as we bring the term into dialogue with the developmental and post-developmental state literature.
} 
private sectors that shape industrial capabilities for generating and absorbing new technologies'. The blurring of public and private within such partnerships (Hall and Hubbard, 1996) has seen national and local states have been drawn into the 'speculative construction of place' (Harvey 1989, p.8). In the process Schumpeterian conceptions of entrepreneurship have been re-applied in a one-sided way by scholars to emphasise the extrasocietal activities of public sectors.

It is here that Mazzucato (2013) reopens debate around the potentially leading role of the state in broader processes of entrepreneurialism (Block 2008), after being 'hollowed out' in past decades. In cases where pre-investment is high and market return unpredictable, direct intervention by the state is plausible to stimulate the entrepreneurial process (Mazzucato, 2013) in a manner that is not too far from the developmental interventionism. The entrepreneurial state literature also notes how the private sector will normally take the lead in developing new products and markets, but what is commonly 'hidden' behind this spontaneity are the incentives provided by state regulations, funding, tax relief etc., that stem from national investment priorities (Eisinger 1988). Governments appear here as brokers between the 'world of regulation' and the 'world of profits'. The question that follows is not whether the state is needed for market development but how to get the state involved in the most effective, productive, and sustainable way. Harvey (1989) and Cox (1993) depicted the transition from managerialism to entrepreneurialism at the local level. Local governments may better positioned to pursue this agenda (Miao 2018), as they carry fewer nationwide public responsibilities while the health of their local economies and tax bases hinge significantly on the attraction of inward investment and skilled labour. Notions of the entrepreneurial state have therefore stimulated discussion and reflection on governmental decentralisation. 
Regardless of whether we are speaking of technological advance (Mazzucato, 2013) or spatial restructuring (Harvey, 1989), the extrasocietally-focused state entrepreneurship profiled in this literature challenges notions of a 'boring, lethargic state' and has captured the imagination of scholars sketching the contours of Asian post/neo-developmental states.

\section{The post-developmental state}

Scholars perceive the developmental state model as 'Asia-specified' (Öniş 1991) with all that this implies for problems of reification given its geographic, sectoral and historical specificity (Yeung, 2016). Thus, the resilience of developmentalism to processes of neoliberalisation, governmental decentralisation and democratic accountability have been questioned (Kim 1993). Since the 1990s, most developmental states have undergone significant restructuring, as captured in the 'post-developmental state' (Thurbon and Weiss 2006; Yeung 2016) and 'neo-developmental state' (Hee-Yeon 2000; Kalinowski 2015) discussions. The term 'entrepreneurial' has been substituted for 'developmental' to describe the re-making of East Asian states (Davis and Ward 1990; Yu 1997).

Arguably, these works have overplayed the contrasts between entrepreneurial and developmental models by adopting a narrow reading of 'entrepreneurship' (The Economist 2013). The extent and nature of changes on the other side of 'stateness' - the intrasocietal adjustments necessary for a state to qualify as 'post-developmental' and 'entrepreneurial' are also not clearly established. ${ }^{2}$ Without an adequate acknowledgement of the legacies of the developmental state model, reformulated versions of neo-/post-developmental states and notions of entrepreneurial states may overlook important aspects of the closely associated processes of economic and state transformation, as well as the reciprocal causation between

\footnotetext{
${ }^{2}$ These issues are compounded by the application of the developmental state model beyond East Asia (Riain 2000; Nee et al., 2007) with Block (2008,p172) arguing that developmental state tendencies were 'hidden' but functioned crucially in targeting resourcing; opening windows; brokering; and facilitating in the USA.
} 
the states' intrasocietal (redistribution within its socio-economic structures) and extrasocietal (extraterritorial economic and diplomatic outreach) functions. Thus, the strategic coupling of post-developmentalism, perceived by Yeung (2016) as a process in which horizontal mechanisms of coordination and indirect incentives have largely replaced the vertical mechanisms of direct intervention of developmentalism, provides one, but not the only, explanation for economic transformation. With its emphasis on partnerships external to the state, the post-developmental state literature is silent on the latitude that has existed within the large and expert public sector bureaucracies.

\section{State intrapraneurialism}

Literature on developmental and entrepreneurial states emerged in the 1980s with some states being described as both $-\mathrm{a}$ fact that is revealing of the fundamentally mixed nature of many modern states. ${ }^{3}$ In reality, as emphasised above, the differences between developmental and entrepreneurial states are ones of degree of high and low stateness (Nettl, 1968). Yet little explored in the overlaps between the two models are questions of how the state can be dynamic from within.

State intrapreneurship can be defined as the latent or actually existing entrepreneurialism apparent within the public sector organisations that make up the state. Evans $(1997$, p.86) notes 'the returns to more innovative forms of stateness ... could be prodigious' and it is our contention that innovative forms of stateness come as much from within (as important legacies of the intrasocietal functions of the developmental state) as from without (as a reflection of the extrasocietal pressures of globalisation in particular).

Modern multinational enterprises (MNEs) organised as part of global production networks are, if anything, more reliant on the competence of states (Evans 1997, p.72).

\footnotetext{
${ }^{3}$ Singapore has been regarded as developmental (Low, 2001) and entrepreneurial (Pereira, 2004); South Korea developmental (Hee-Yeon, 2000) but also networked (entrepreneurial) (Larson and Park, 2014); China developmental (Nee et al., 2007) yet entrepreneurial (Duckett, 1996).
} 
Moreover, "in an economy of "ideas" subject to increasing returns rather than "things" subject to decreasing ones ... the magnitude of returns ... depend[s] on authoritative decisions' (Evans 1997, p.77). In order to understand these intrasocietal dynamics that are the pre-conditions for the extrasocietal functioning of developmental, entrepreneurial and post-developmental states alike, we reconsider the centrality of the state to Schumpeterian processes of entrepreneurialism and innovation in the form of: (1) new products/services; (2) new processes; (3) new inputs; (4) new markets and; (5) new organisations. Figure 1 presents a framework which combines the key features of the developmental state (the features connected horizontally) and the entrepreneurial state model (running vertically in the form of a pyramid). The overlap between the two models comprises our organising framework for understanding the intrapreneurial state. In order to further specify the sources and functions of intrapreneurialism implied in this overlap, there are three further observations we make.

Figure 1. The conjoined framework of developmental and entrepreneurial state Source: the authors

\section{Continued state leadership in the setting of industrial priorities}

The designing of industrial priorities provides the point of overlap between the entrepreneurial and developmental state models, and reveals the 'strategic selectivity' of the state (Jessop 1990) as an act akin to entrepreneurship. As well as strategic selectivity, there are two further sources of entrepreneurialism associated with leadership in the setting of industrial priorities. First, specialisation within states may embody intrapreneurship. Majone (1989) has argued that the policy making process has itself become more 'roundabout'. One of the barely elaborated implications of this observation is that states are a source of entrepreneurship with regard to the development of new products/services, new processes 
and new organisational forms. Yu (1999, p.756) offered a detailed account of how public entrepreneurs imagine and identify growth opportunities, elaborate them, and then make decisions to undertake new projects in order to capture them, which applies equally to leadership exercised within developmental states. States overtly create new markets by way of regulations but also do so more subtly as intermediaries in a process of 'economization' (Berman 2014), stimulating the division of labour commonly associated with the private sector. Just as in the private sector (Howells 1989), the process of identifying and developing new products, services and markets within state is one of experimentation leading to new specialist state, quasi-state and private organisations. Second, since the division of labour is limited by the extent of the market, the territoriality of the state is an analytical trap (Agnew 1994) to be avoided and 'spatial selectivity' (Jones 1999) something to be alert to when considering state intrapreneurialism. The spatial selectivity apparent in the extraterritorial reach of states highlights intrapreneurshp as an intrasocietal pre-requisite for the sorts of extrasocietal sources of transformation emphasised in much of the extant literature. Entrepreneurial strategies can include the spatially-selective opening of new domestic markets (via marketing and/or modifying consumption through enhancing the quality of life for residents, commuters or visitors) (Jessop and Sum 2000). Historically, states have also acted extra-territorially to secure inputs and develop markets. The most intrapreneurial states historically and presently have done so in a variety of ways not least because 'sovereigntyin the sense of socially constructed practices of political authority-may be exercised nonterritorially or in scattered pockets connected by flows across space-spanning networks (Agnew 2005, p.441). For small states such intrapreneurialism is necessarily extra-territorial. Something as 'mundane' as the attraction of FDI can involve 'strategies that are as complex as those adopted by private firms' (Encarnation and Wells 1986, p.267). The political behaviour of MNEs can produce a store of future economic value but can be mirrored by the 
soft power of extra-territorial actions designed to mobilise reputation or brand extrasocietally as an economic asset (Anholt 2007). ${ }^{4}$ Small states have been particularly adept with regard to international diplomacy centred on economic development goals (Baldacchino 2010; Cooper and Shaw 2009).

\section{The leadership and action power present in partnership}

In both entrepreneurial and post-developmental state models, it is public-private partnerships that are said to define industrial priorities. These public-private partnerships are central to processes of strategic coupling in which post-developmental states engage with global production networks. For Yeung (2016, p.20), we have entered 'a new era in the politics of development when capitalist national firms have outgrown their domestic institutions and become the main actors in subsequent rounds of industrial transformation'.

However leadership may come as much from the state as from the private sector. Harvey (1989, p.7) argued that: 'coalition and alliance formation is so delicate and difficult a task that the way is open here for a person of vision, tenacity, and skill ... to put a particular stamp upon the nature and direction of urban entrepreneurialism, perhaps to shape it, even, to particular political ends'. For Pasotti (2010, p.13) entrepreneurial government leadership centres on brand politics since, 'politics and markets are converging in their operational logics ... The basis for this convergence is that entrepreneurs in both spaces increasingly pursue their goals of consensus and profit maximization by manipulating preferences and striving to shape new values and identities'.

Moreover, partnership arrangements also appear likely in many instances to have their bases in the action power mobilised by developmental states. In contrast to much institutional economics, the developmental state literature reminds us that state-owned or linked enterprises have been a means to initiate action with regard to collective action

\footnotetext{
${ }^{4}$ China's state extra-territoriality is driven by issues of resource security but overseas industry parks established in Africa also exert soft power (Brautigam and Tang, 2011).
} 
problems involving inter-dependent investment decisions (Bardhan, 2016) perhaps prior to privatisation. This is partially derived from the motivation-sanction mechanism needed for a coherent partnership, but more so in signalling the visions and benefits of it. Larson and Park (2014) argue that South Korea had transformed into a network state, in which some powerful chaebol industrial groups could effectively influence the industrial priority setting of the country. Nonetheless, they also acknowledged the continuing explanatory power of a competent bureaucracy. This included the 'market conforming methods for state intervention, but more importantly, the control structured around the state and its agencies, to oversee the implementation and evaluation of industrial strategies designed by its private-public partnership' (ibid, p.344). Among the six factors underpinning a functioning partnership (Mattessich and Monsey 1992), financial capability and risk tolerance are the key (Johnson 1989) and these, in turn, have become features of the public sector (Mazzucato 2013) rather than the private sector.

\section{The outcome-oriented nature of intrapreneurship}

The relationship between policy and its outputs remains poorly understood in the academic literature and yet is well understood within developmental state practice, whereby states typically internalize the positive effects of their own policies. This emphasises not so much the extent of intervention but its quality via feedback mechanisms (Bardhan 2016, p.867). Thus we suggest that it is the feedback mechanism in Figure 1 that provides an enduring legacy of developmentalism in any post-developmental transition.

'Public agents are entrepreneurial when they are alert to change, and discover and exploit opportunities' (Yu 1997, p.51). Entrepreneurial states in turn 'measure the performance of their agencies, focusing not on inputs but on outcomes. They are driven by their goals - their missions - not by their rules and regulations' (Osborne and Gaebler, 1992:20). The challenge here, for developmental and entrepreneurial states alike, is how to 
manage risk in public accountability and control excessive public deficits (The Economist 2013). These intrasocietal challenges raise the necessity of flexible implementation, monitoring and evaluation of the risk-return balance. Lessons learned, in turn, provide valuable inputs to state leadership and partnership, stimulating public learning and error elimination, and even significant structural reforms and priority alterations (Miao and Hall 2013).

That is, the emerging meta-regulatory role for governments (Levi-Faur 2005) is predicated on specialization within the state itself. Thus, 'While globalization does make it harder for states to exercise economic initiative, it also increases both the potential returns from effective state action and the costs of incompetence' (Evans, 1997: 74). In this connection, something as mundane as monitoring can be important for state intrapraneurship since it helps to alleviate the tendency for institutional amnesia - all too apparent in an age when information is ubiquitous (Pollitt 2000) - and the governmental inefficiency associated with excessive policy churn.

\section{Methodology}

We seek to illustrate state intrapreneurship by portraying the emergence of Singapore's smart/sustainable city solutions sector. Singapore is a representative case to examine the central theme of this paper given that its development is considered to show signs of both entrepreneurialism and developmentalism. Therefore we treat Singapore as one of the best places to start the discussion on the possible mechanisms of auto-transformation found within developmental states and aspects of intrapreneurialism specifically.

Two complementary data sources were used in this research. First, we referred to secondary data sources such as a significant extant academic literature speaking to policy development in Singapore as well as official policy documents and websites. Concerns have been raised regarding the lack of controls over secondary data generation (Hakim 1982), but 
use of these sources is important since this study involves tracing organisational developments over recent decades which interviewees may not recall accurately.

Second, a series of face-to-face interviews were conducted with senior officers from some of the major public agencies and GLCs. We conducted 14 interviews in Singapore and China with, among others, Economic Development Board (EDB), IE Singapore, Housing Development Board, Surbana Corporation, Centre for Liveable Cities (CLC), Singapore Cooperative Enterprise (SCE), Ascendas, and Singapore Chinese Chamber of Commerce, between September and October 2015. Interviews were semi-structured around the topics of the connections between development and entrepreneurship. There are limitations to the use of elite interviews as a research method (Harvey 2011) and there is the potential problem of interviewees uncritically replicating the 'Singapore story' - a story which has been carefully cultivated at home. Nevertheless, the interview method was appropriate and vital to generating a more detailed understanding of the subject of state intrapreneurship. Moreover, the position of the interview informants - typically directors or deputy directors of the organisations concerned - generated a strong measure of critical reflexivity in responses and ensured the validity of this particular method.

\section{Intrapreneurialism in the Smart/Sustainable Urban Solutions Field}

For Evans (1997), Singapore represented a case of high stateness par excellence, given the capacity of its state bureaucracy in bargaining with MNEs. However, the intrapreneurialism of the Singaporean state in continuously repositioning itself is no less significant than the role of the private sector in subsequent processes of state and economic transformation. When Singapore gained independence in 1965, it had extremely fragile economic foundations with high unemployment, an extremely limited industrial structure and almost no natural resources (Gross 2010). This situation helped cultivate an awareness of potential crisis among the first generation leaders, and the health of the economy emerged as the overriding strategic priority. 
Singapore shifted its economic growth strategy from import substitution to export stimulation as early as the 1970s, and constructed a 'two-leg' growth engine composed of GLCs and MNEs. Its Economic Development Board (EDB) was set up to oversee the industrialisation process and continues to hold a decisive role in implementing national priorities (Tay and Soh 2015). Such was the success of the Singapore economy that it became home to increasingly capital intensive manufacturing and service industries - labour intensive industries being offshored initially to its immediate hinterlands in Malaysia and Indonesia as part of a 'growth triangle' arrangement (Phelps 2004), and then further afield to support a broader regionalisation strategy, resulting in the growth of the domestic economy but also a state apparatus steering that process (Pereira 2004; Phelps 2007). Today, EDB has been joined by a raft of specialised agencies that reflect the diversity and strength of the Singapore economy as exporter and overseas investor.

For Lan (2001, p.3), 'industrialisation per se has been the priority [of developmental states], not considerations of maximising profitability based on current comparative advantage'. This was true of the early industrialisation of Singapore, when export promotion and attraction of MNEs was the immediate aim (Lee 2000). However, since the late 1970s, the leadership in Singapore has strategically selected the most promising sectors that fit the city-State's evolving competitive advantages, something underlined by an interviewee from Ascendas (personal communication, September 15, 2015). In its 2015 budgetary plan, five industrial priorities were identified, including advanced manufacturing, applied health sciences, smart and sustainable urban solutions, logistics and aerospace, and Asian and global finance services. Among these, 'the smart and sustainable urban solutions' (SSUS) sector is interesting, as at first glance, it appears as strategic selection of a brand new sector. One nearest sector to SSUS, Real Estate, remains a modest contributor to outward FDI from Singapore compared to manufacturing, finance and insurance, but it has a growing weight in 
the accumulated stock of Singapore's outward FDI from $6.6 \%$ in 1994 to $7.7 \%$ in $2014 .{ }^{5}$ Yet, during these two decades Singapore has emerged as a model of city planning and development across Asia and indeed globally (Chua 2011; Pow 2014). ${ }^{6}$

\section{Intrapreneurial leadership and priority setting in the SSUS field}

Ironically, the urban image and substance of Singapore, so widely aspired to by politicians and technocrats across the world, are those the city state had to learn and adapt from international experience in the first instance (Lee 2000). When there was no ready-made model to look to, Singapore relied on its Ministries and government agencies, GLCs, and later privatised GLCs for what have come to be regarded as self-made solutions (Lee 2000). The key points here, as emphasised by one of our interviewees (SCE, personal communication, September 18, 2015), have been the ostensibly 'greenfield' industrialisation and urbanisation and the build-up of in-house capability and human resources that stood the Singapore government agencies in good stead to pick its industrial priorities, and subsequently, export the 'Singapore model'. Almost all of the government agencies created at the outset or soon after Singapore's independence have evolved, expanded and spawned new international divisions and specialist organisations. One interviewee from IE noted the problems of the growing scale and complexity of the Singapore economy that arise from corresponding specialisation in Government functions (personal communication, September 16, 2015). It also becomes clear that Singapore state's internal restructuring went hand in hand with its extra-territorial activities, which were intimately associated with its intrapreneurial capacities.

\footnotetext{
5 Source: http://www.singstat.gov.sg/statistics/browse-by-theme/investment-tables (accessed 31 January 2017).

${ }^{6}$ Singapore was mooted (with Switzerland and Norway) as a potential small state model for the UK following the referendum decision to exit the European Union (Skilling, 2016). Switzerland was itself the benchmark for Singapore at the time of its regionalisation strategy (Interview, Ascendas: $15^{\text {th }}$ Sep 2015).
} 
The top-level institutions involved in the design of Singapore's strategic priorities are: the Economic Development Board (EDB), established in 1957 to fashion an economy from overseas investment; the Ministry of National Development (MND) established in 1959, responsible for land planning, urban development, construction and open spaces management (MND 2015) and; the Ministry of Environment (later named Ministry of the Environment and Water Resources) formed in 1972, to tackle various environmental issues (MEWR 2015). Famously, these early institutions helped transform Singapore into a garden city after former PM Lee's initial vision, and planted the seeds of its present comparative advantage in, and industrial priority of, SSUS.

Nonetheless, most of the investments by these public institutions were regarded as public infrastructure even in the pioneer Jurong Industrial Township, where first-class urban design and land planning were seen as necessary to attract foreign investment but with minimal value attached to these activities per se. The economic consequence of the knowledge accumulated in these spheres only became apparent by the 1980 s, when the success in attracting manufacturing FDI prompted a remarkable piece of state intrapreneurship in the search to ameliorate some of the 'overheating' of the Singapore economy at that time. The intrapreneurship centred on fashioning a hinterland for Singaporeanchored manufacturing industries in the adjacent territories of Indonesia and Malaysia, as part of the so-called Indonesia-Malaysia-Singapore Growth Triangle (IMS-GT) (Phelps, 2004). Notable here was a first 'official' experiment with the government-to-government financing, planning, development and operation of an overseas industry park - Batamindo in Indonesia (Perry and Yeoh, 1988). Subsequently, the experience in deploying elements of the Singapore model overseas was orchestrated by EDB, and allowed Singapore's key corporations (such as Ascendas, Sembcorp and Surbana) to share knowledge and progressively generate the 'dynamic capabilities' (Teece et al. 1997) or 'ownership 
advantages' (Dunning 1980) that were the basis of their subsequent internationalisation (Ascendas, personal communication, September 15, 2015). Such experience also formed the basis of further state intrapreneurialism in a regionalisation strategy, which increased the breadth and depth of this hinterland with the addition of three other 'official' overseas industry and technology enclaves (in Bangalore, India and Thu Dau Mot, Vietnam) and the more comprehensive China-Singapore Suzhou Industrial Park (SIP) (Perry and Yeoh 2000).

Although many Singaporeans doubted the decision to support these countries in grasping the 'Singapore way of doing business' (Lee 2000), the returns, in building the reputation of Singapore in integrated urban planning and management, environmental protection and innovative industrial space design, is apparent by now and increasingly materialised by its domestic companies. This regionalisation strategy evolved into a globalisation strategy with an increasingly complex division of labour, both within the state and among the state, quasi-state, and private actors home and abroad. This evolution thus offers initial evidence on how intrasocietal state dynamics paved the way for subsequent extrasocietal transformation. However, the 'Singapore story' also continues in a reciprocal loop where the state's developmental effort soon stimulated further intrapreneurial restructuring: As a direct result of the extra-territoriality described above, a new agency Singapore IE - has been carved out of the Ministry of Finance to provide support for outward investment and export promotion. Originally a regulatory-oriented board of trade within the Ministry of Finance dealing with the likes of import/export licensing, it was transformed in the late 1980s as a result of lobbying from the business community to take on a wider and more proactive remit, and then augmented again in 1997 as a stronger and more visible agency in support of the globalisation strategy (IE, personal communication, September 16, 2015). 
As this reciprocal relation between the state's intrasocietal and extrasocietal dynamics evolves, other Ministries and their boards have adjusted too in ways that specifically reflect and support this new industrial priority. MND had been extended from a handful of divisions in 1961 to nine agencies and eleven divisions/departments by 2015 (MND 2015). Its two latest agencies include Eco-City Project Office and Centre for Liveable Cities, both of which focus on promoting the Singapore model in general and supporting SSUS in particular. EDB also underwent several rounds of restructuring in order to further divide and specify its functions (Wong 2007): The Jurong Town Corporation (JTC) was created in 1967 to take over EDB's industrial real estate development function, and has become the major player in spearheading the development of Singapore's industrial landscape (Tan 1999). JTC itself was corporatized in 2000 in order to be more market-facing and to expand its global reach (National Library Board 2010). A wholly-owned subsidiary of JTC, Jurong International Holdings, was established specifically to offer SSUS to international clients.

On the financial side, Temasek Holdings Limited (THL) is the major player. Formed in 1974 as Singapore's investment company in local GLCs, THL had over time shifted its role from a pure representative for the government to be more entrepreneur-like by stimulating strategic ventures (Forshaw 2011). In the new century, THL launched a series of restructurings in order to better support world-class enterprises and monitor the diversification plans of GLCs (Low 2001, p.421). In terms of SSUS, THL and JTC reconfigured four of their operating subsidiaries into one integrated platform in September 2014 (Temasek 2014). The Deputy Director of Housing Development Board commented that:

'Such concentration of resources signifies the government's intention in minimising duplication and competition internally. It also crystallizes the key players in this field, with the hope to form an anchor company in leveraging the internationally competitive of the whole industrial sector ... maybe such 
flexibility, urged by the State, is one of the key ingredients of the so-called "Singapore model"” (personal communication, September 17, 2015).

This interviewee's comment highlights the leadership apparent in the significant organisational intrapreneurship of Singapore.

Returning to figure 1, we can observe how extraterritoriality has been both the subject of initial state intrapreneurship surrounding the securing of new hinterland inputs (land and labour), and latterly became an input itself to state intrapreneurship in securing overseas markets for the emerging SSUS industrial priority specifically. One senior interviewee highlighted how a price could not be put on the value of the SIP venture in China; for all of the acknowledged difficulties (Pereira, 2002), this venture had opened the Chinese market to Singapore's private sector, and provided a vital training ground for both Singapore and Chinese civil servants, many of whom had moved on to obtain more senior government positions yet maintained their cross-border mediatory role (IE, personal communication, September 16, 2015).

With each of the three major Singapore-connected projects in China, IE Singapore has opened an office, which is supplemented by the establishment of Singapore-China Business Councils. The latter are oriented to discussing and resolving business frictions but also serve as valuable listening posts to gauge emerging business opportunities in China (IE, personal communication, September 16, 2015). Changes in how China is viewed within Singapore government circles have been the main stimulus for this. As our interviewee described,

'In the past we used to look to China for the sake of tapping the market. Sell something to China or produce something in China. Today we look at China quite differently. When we speak about technology we cannot ignore what is going on in China. Some of the most cutting-edge things that are happening - supply chain and business models - are from China. So we are paying closer attention to this country' (IE, personal communication, September 16, 2015). 
These observations extend to the SSUS field as revealed by the story of organisational restructuring and expanding market presence centred on the Housing Development Board (HDB). At the time SIP was being mooted in the 1980s, the HDB was, as a Singapore government body, unable to be involved in master planning despite requests from the Chinese government. However, in recognition of this lost opportunity, HDB quickly formed a new venture - CESMA International - in 1989 through which it later participated in SIP and a series of other official and unofficial developments across Southeast Asia and China. CESMA was fully corporatized into Surbana in 2003 and since then has been involved in projects further afield in India, the Middle East and Africa. In the first instance, several of these overseas developments were solely or primarily commercial, but now Singapore consortia including Surbana are only involved in mixed-use developments, precisely for the pragmatic reason that profit margins are higher for residential than commercial developments (Surbana, personal communication, September 14, 2015), as exemplified in its latest Tianjin Eco-City investment portfolio (Tianjin Eco-City Planning Bureau, personal communication, October 12, 2015). Moreover, despite the legend of the Singapore model, our interviewee noted significant competition from both national planning institutes and major MNEs operating in China, so that Surbana had embarked on a series of acquisitions partly to build additional capabilities. The same interviewee also noted how the original neighbourhood unit model pioneered by the HDB has evolved several times - with greater densities now beginning to emerge in Singapore that resemble those, and reflect the influence of, Chinese practice (Surbana, personal communication, September 14, 2015). The deeper insight that this example of state intrapreneuralism offers lies in the strengthened policy learning and resource mobilising capabilities generated through the reciprocal relationship between the state's intrasocietal and extrasocietal functions. 
Since the early 2000s, green technology, urban management and smart growth have become salient and Singapore responded quickly in capitalising on its reputation in this field. In 2014 the PM Lee Hsien Loong launched a new vision for the city-state to be the 'world's leading Smart Nation' where 'people live meaningful and fulfilled lives, enabled seamlessly by technology, offering exciting opportunities for all' (Cheam 2015). In 2015, 'Smart and Sustainable Urban Solutions' was formally chosen by Singapore as one of its five key growth areas, which demonstrated the State's role in creating new sectors and products. Again topdown intrapreneurial leadership is far from absent in this process as our interviewee from IE Singapore revealed another story:

'In my mind the Singapore government has been very careful in picking the 'winners' as the next strategic sectors. Quite often, the attempt to develop new sectors will involve intensive discussions with independent consultants and industrial leaders. We now have the sustainable urban solutions as one of our priority areas, because we have all the necessary institutional, physical, commercial and financial infrastructures ready, and our companies are confident in leading this emerging market' (personal communication, September 16, 2015).

An extended 'embedded authoritarianism' has been apparent in the fashioning of this new strategic priority, as will be discussed below.

\section{The action power in partnerships in the SSUS field}

The crucial role played by the People's Action Party (PAP) in creating the 'Singapore model' is well documented (Lee 2000; Low 2001). Nonetheless, the Singapore State increasingly relies on various elite alliances both within PAP and in the wider society for achieving what has been described as 'embedded authoritarianism' (Chua 1995, p.59). One case in point is the delicate relationship between PAP and the majority ethnic Chinese Community in Singapore (Haque 2004). The former President of the Singapore Chinese Chamber of Commerce remarked that: 
'The establishment of our organisation was highly supported by PAP, and our Committee members normally serve in various important government agencies such as EDB. We are heard and supported by PAP as there are many ways for us to get involved in the decision making process, and we are quite often consulted in the making of strategic decisions' (personal communication, September 10, 2015).

Partnerships between the government and companies have also played a particularly important role in Singapore's SSUS agenda. To foster such partnerships, Singapore has positioned itself as a 'living laboratory', in which domestic and foreign companies are encouraged to test and commercialise innovative solutions using its urban infrastructure (Calder, 2016). In this arrangement, companies benefit from perfecting their products in Singapore before scaling up for the wider Asian and global markets. Singapore also benefits from accessing state-of-the-art technologies when being regarded as the 'showcase' of future, sustainable urban growth worldwide ${ }^{7}$. Moreover, partners enjoy great freedom in piloting projects under the umbrella of the SSUS state priority. Panasonic is using Punggol Eco-Town in Singapore to test and commercialise its 'total energy solution'. Siemens is pioneering $\mathrm{CO}_{2}$ reduction opportunities in the Tampines district (Webb 2012). At the same time, the Singapore government, through its pilot agencies and GLCs, is also proactive in exploring new market opportunities; EDB and Veolia (France) have a joint Sustainable Cities Centre of Excellence for the design and planning of eco-towns (Yip 2013). In the area of clean technology solutions, MNEs, SMEs, GLCs and various state agencies were involved in what the Chairman of the Centre for Liveable Cities (CLC) described as a 'collaborative alignment' approach (personal communication, September 18, 2015). These emerging interorganisational networks capturing SSUS potentials require flexible institutional

\footnotetext{
7 Singapore was ranked the smartest global city by Juniper Research (https://www.juniperresearch.com/press/press-releases/singapore-named-global-smart-city-2016, assessed on 12/02/2017.
} 
arrangements, quick reaction to the market, and innovative financial arrangements, which further pushes reconfigurations in state agencies and GLCs. The feedback loop between leadership, partnership and action power of the state (figure 1) consolidates this process.

The conception and operation of overseas industrial parks demonstrate state intrapraneurship in arriving at the SSUS priority but they also have provided the test-bed for new products/services and new working processes for its agencies involved in this sector. In many of these overseas ventures, an inbuilt 'knowledge transfer' package on planning and industrial space management was exported (Tan 1995), which not only leveraged the physical built environment of these estates, but also enhanced the reputation of Singapore in the SSUS field. A bilateral 'Knowledge Transfer Office' was set up under the Ministry of Trade and Industry in Singapore and SIP when the latter was established in 1992 (Pereira 2002). Its three-level transfer packages, regular training and manager rotations have helped SIP to become an 'exporter' of a modified Singapore model suitable for China to other domestic regions (Director of SIP Learning Singapore Experience Office, personal communication, October 14, 2015). Since then China had quickly become the largest client of 'Singapore solutions' (Zhang 2012), allowing Singapore to mobilise its Chinese ethnic and social ties to maximise potential returns. One case in point is the targeted training programmes offered to senior Chinese officials by Nanyang Centre for Public Administration, whose qualification was recognised the earliest by the State Administration of Foreign Experts Affairs in China. In this sense, state intrapreneurialism plays a strong steering role in shaping extrasocietal relations and reputation.

Entering the new century, the Asian market is changing which requires the adaptation of the Singapore state as mentioned earlier by our interviewee from IE Singapore. The marketing officers of CLC revealed two reasons: 
'It seems to us that many Asian countries are getting richer, and become pickier of whom they want to learn from. We are increasingly competing with consultants from North America and European regions. On the other hand, Singapore's expertise in the more traditional industrial estates needs upgrading, as our partners copy quickly the techniques of planning and the designs of infrastructure' (personal communication, September 18, 2015).

Correspondingly, Singapore adjusted its orientation through two main approaches. Firstly, The Singapore government has increasingly been drawn to and invested in its own capabilities with regard to South America and Africa as potential markets. According to the Deputy Chairman of IE Singapore,

'We invest in wherever our companies want to do businesses. There is substantial market expansion in Africa for example among our manufacturing companies, so we go there, talk to the local and Central governments, sign memorandums, and formalise a pro-Singapore network. We want to make sure our companies have a benign environment there' (personal communication, September 16, 2015).

Secondly, Singapore has upgraded its products/services offer to 'smart/sustainable urban solutions' - something yet to be fully exploited even in developed countries - providing it with a lucrative market. For example, Singapore's electronic road pricing system has been studied by various global cities (Chua 2011, p.33). London and Melbourne had already put in place a version of this system. In China, Singapore's latest investment was the Tianjin Ecocity commenced in 1996. Instead of helping Tianjin attract FDI and building factories as with SIP, the purpose of this Eco-city was to trial the feasibility, replicability and effectiveness of Singapore's SSUS capabilities before rolling them out across China. Outcome-based market exploration has won Singapore a leading position in the global smart city market. This is achieved through its continuous market monitoring and risk taking, as well as strong and 
decisive State support and investment - an intrapreneurial ingredient of a state that has mixed developmental-entrepreneurial credentials - to which we now turn.

\section{Outcomes as feedback in SSUS strategic priority}

Market outcomes are crucial indicators for developmental states' priority settings as shown in Singapore's exploration of the SSUS strategy. Overseas industry parks have provided not just markets or additional labour inputs for established manufacturing industries but also test-beds - knowledge inputs - for what was to be Singapore's latest strategic priority. Subsequently, these opportunities have been further amplified by 'many instances in which Singaporean public policies and state entrepreneurial activities have been studied and copied by other governments' (Chua 2011, p.32). Singapore is doubly advantaged in its ability to deploy extraterritoriality; as a city state it participates in fora intended for nation states and city governments and leaders (Calder 2016, p.150). Much of the high demand from overseas governments for study visits to Singapore is still handled in a very decentralised way (IE, personal communication, September 16, 2015). However, reorganisation and innovation have been aimed as much at facilitating strong market outcomes as improving coordination.

Even something as simple as documenting the Singapore pathway has produced business opportunities and innovation within government agencies. One of the latest reconfigurations between MND and MEWR is the creation of the Centre for Liveable Cities (CLC) in 2008, which functions as a Think-Tank specialised in sustainable urban development, and the focus point and front desk in broadcasting Singapore's SSUS industry. It achieved this by providing tailor-made products and services to other countries and cities based on Singapore's expertise. Its 'Leaders in Urban Governance Programme', with a starting cost of $\mathbf{\$} \$ 15,000$ (10,561 USD), offers a four-week study in Singapore, comprising of in-class workshops and seminars, site visits of private and public promises, and overseas field trips. Moreover, CLC has taken on activities with an outward facing remit such as 
organising international mega-events. Its 2012 World Cities Summit drew over 19,000 participants from more than 100 countries ( $\mathrm{Ng} 2012$ ), which further strengthened the role of Singapore as a world leader in SSUSs and demonstrated Singapore's efforts to build a platform that goes beyond the island's shores (Gross 2010). Table 1 provides an indication of the scale and variety of activities coordinated by CLC in recent years. Geographical breakdowns of participants to the World Cities Summit Mayors Forum revealed the weight of interest from African nations and cities. On average participants from this region have made up one half of all participants between 2008 and $2012 .^{8}$

Table 1 Capability development and advisory activities by CLC Source: Central for Liveable Cities (CLC 2017)

The interest of visiting delegations is less in Singapore as it is today than in how Singapore has achieved what it has (CLC, personal communication, September 18, 2015). The same interviewee noted that another mission of CLC has therefore been to document the Singapore story and the practices that lie behind its success while those directly involved are still alive. This emphasis on the mundane of documenting 'old' knowledge and monitoring and evaluating policies is important to realising future economic value, and contrasts starkly with the policy churn and institutional amnesia associated with liberal market states (Pollitt, 2000). It can be contrasted with the British new towns which, although widely studied and copied, were neither properly evaluated nor systematically exploited by the British government or allied private sectors. Here Singapore's state intrapreneurialism has been a key contributor to both its wider intrasocietal legitimacy but also its extrasocietal reputation.

\footnotetext{
${ }^{8}$ Source: http://www.clc.gov.sg/documents/annualreport doc/CLCAR1213Book.pdf
} 
State intrapreneuriaship is revealed in the fact that strategic priorities are never just priorities without an outcome. Singapore Cooperation Enterprise (SCE) is a government agency that now sits within IE Singapore. It was formed by the MFA and the MTI in 2006 in order to coordinate requests for visits to these two ministries. Some indication of the extent and magnitude of the international market generated around the priority of SSUS is provided by the fact that, for the SCE, China used to be its largest customer before 2014 with delegates peaking at over 2000 in three months (personal communication, September 18, 2015). Since its formation, SCE has undertaken 200 projects in over 40 countries, and signed numerous memoranda of understanding (figure 2) (SCE 2016), though these are heavily skewed towards China and Asia-Pacific. However, even for a body like SCE,

'We don't just do something for the sake of doing it ... but rather what are the implications of handling these requests? ... We have two objectives. One is the diplomatic one. The other one, from MTI's point of view, is to bring Singapore companies overseas' (SCE, personal communication, September 18, 2015).

Figure 2 Memoranda of understandings signed by SCE Source: Adapted from SCE (2016)

These twin objectives converge in the case of SSUS around which much of the current interest from overseas centred. Moreover, we noticed that outcomes had become even the focus of who was trained. Our interviewee noted how they seek to train mid-level civil servants who are able either to sign off, or advocate for, given projects in their home countries, or are seen as being likely to rise to higher levels of government in the near future (SCE, personal communication, September 18, 2015). By helping to build intrasocietal state 
capacity abroad, the Singapore state has strengthened its own extrasocietal reputation and influence.

\section{Conclusion}

As two accounts rivalling minimalist state ideology, developmental and entrepreneurial state theories were developed in parallel to emphasise the persistent, albeit adjusted, roles of the state in dealing with external pressures from globalisation, decentralisation and neoliberalisation. In this paper, we have sought to link these two models in an organising framework that draws attention to state inrapreneurialism as part of the intrasocietal dynamics of states, as well as a reaction to extrasocietal pressures. Using the Singapore state and its strategic promotion of the smart/sustainable urban solutions sector to illustrate the contribution of state intrapreneurialism, we believe this paper further contributes to an understanding of processes of post- or neo-developmental state transformation in Asia.

Our evidence on the emergence of SSUS in Singapore suggested how the emergence of this priority involved significant state intrapreneurialism based on path dependent opportunities. Singapore's accumulated expertise with land planning, infrastructure management and natural resource protection conferred a lead in the 'urban solutions' market upon this city-state - a lead consciously nurtured by the state through its pilot agencies and GLCs. For the state to adjust its priority setting, several interorganisational networks are mobilised for assembling evidence, financing and exploring market potentials. An interesting question arising is for how long Singapore's state-dominated leadership can remain valid, given its ambition to become the world's 'living laboratory'. The fact that MNEs are using whole estates or districts of Singapore as testbeds for their urban solutions suggests the possibility that Singapore's next industrial priority may indeed emerge from these private laboratories, changing once again the partnership-leadership structure. 
We believe the case of Singapore is appropriate to examine ideas of state intrapreneurialism. Yet 'Singapore is at once an anomalous outlier and a potentially evocative paradigm' (Calder, 2016, p.163). On the one hand, it is unique and non-replicable given its city-state, one-party character. Moreover, the embryonic nature of the SSUS industry in Singapore requires further study in order to trace its growth trajectory - perhaps in comparative perspective. On the other hand, the Singapore state has departed least from the developmental state model (Yeung, 2016) and the value of the case can be seen in how many of Singapore's Asian neighbouring states are also investing heavily and developing expertise in this particular industry sector in a process of catch up. In the case of China, around 200 smart city platforms and approximately 400 eco-cities have been launched. The scale of its domestic market is a significant source of the 'ownership advantages' (Dunning, 1980) or 'dynamic capabilities' (Teece, 1997) that are said to drive the expansion of MNEs. 'Like Japan and Korea before it, yet in a more globalized way, Singapore has worked systematically not only to generate ideas of technical significance but also to test and to commercialize them - becoming a "living laboratory" ... focused on operationalizing realworld applications' (Calder, 2016, p.140). It will be interesting to observe how processes of catch up in this SSUS industry could prompt further intrapreneurialism on the part of states in decades to come.

Curiously, for all its emphasis on public-private partnerships, the post-developmental state literature tends to reinstate a residual sense of the state-market dichotomy that the developmental state literature rather overcame. Yet, the entrepreneurial state model does not capture fully the extent, nature or sources of state intrapreneurialism. Although the developmental state model increasingly appears a period piece, conjoined with elements found in the entrepreneurial state literature, it continues to offer value in an explanation of the linked processes of state and economic transformation. The issues we explore in this paper 
underline the value of bringing the (post)developmental state literature into dialogue with the mainstream of institutional economics of the state (Bardhan, 2016). Overly strident oppositions between the developmental state, on the one hand, and entrepreneurial, post- or neo-developmental state models, on the other, may obscure important continuities that exist in institutional-economic transformations.

Acknowledgements

We are grateful to John Agnew and to the journal referees for their insightful comments on this paper. We also gratefully acknowledge the British Academy (Grant number SG140879) for funding the research upon which this paper is based. 


\section{References}

Agnew, John (1994), 'The territorial trap: the geographical assumptions of international relations theory', Review of international political economy, 1, 53-80.

--- (2005) 'Sovereignty regimes: territoriality and state authorityin contemporary world politics', Association of American Geographers 95:437-461

Anholt, Simon (2007), Competitive Identity: The New Brand Management for Nations, Cities and Regions (Basingstoke: Palgrave-Macmillan).

Baldacchino, Godfrey (2010), Island enclaves: Offshoring strategies, creative governance, and subnational island jurisdictions (Montreal: McGill-Queen's University Press).

Bardhan, P. (2016) 'State and development:the need for a reappraisal of the current literature', Journalof Economic Literature 54, 862-892

Berman, Elizabeth Popp (2014), 'Not Just Neoliberalism: Economization in US Science and Technology Policy', Science, Technology, \& Human Values, 39 (3), 397-431.

Blecher, Marc (1991), 'Development State, Entrepreneurial State: The Political Economy of Socialist Reform in Xinju Municipality and Guanghan County', in Gordon White (ed.), The Chinese State in the Era of Economic Reform: The Road to Crisis (London: Palgrave-Macmillan UK), 265-91.

Block, Fred (2008), 'Swimming Against the Current: The Rise of a Hidden Developmental State in the United States', Politics \& Society, 36, 169-206.

Calder, K. (2016) Singapore: Smart City, Smart State. Washington DC: Brookings Institution).

Cheam, Jessica, (2015), 'Smart and Sustainable Singapore: Two sides of the same coin?'. The Straits Times, published on 21st July 2015: (http://www.straitstimes.com/opinion/smart-and-sustainable-singapore-two-sides-ofthe-same-coin)

Chu, Yin-wah (2009), 'Eclipse or reconfigured? South Korea's developmental state and challenges of the global knowledge economy', Economy and Society 38, 278-303.

Chua, Beng Huat (1995), Communitarian Ideology and Democracy in Singapore (London: Routledge).

--- (2011), 'Singapore as Model: Planning Innovations, Knowledge Experts', in Ananya Roy and Aihwa Ong (eds.), Worlding Cities: Asian Experiments and the Art of Being Global (Oxford: Blackwell Publishing ), 29-55.

CLC, Singapore, (2017), 'Annual Report'. Centre for Liveable Cities, Singapore: http://www.clc.gov.sg/Publications/annualreport.htm

Cooper, Andrew F. and Shaw, Timothy M. (2009), The diplomacies of small states (Basingstoke: Palgrave Macmillan).

Davis, David R. and Ward, Michael D. (1990), 'The Entrepreneurial State: Evidence from Taiwan', Comparative Political Studies, 23, 314-33.

Dunning, John H. (1980), 'Toward an Eclectic Theory of International Production: Some Empirical Tests', Journal of International Business Studies, 11 (1), 9-31.

Duvall, Raymond D. and Freeman, John R. (1983), 'The Techno-Bureaucratic Elite and the Entrepreneurial State in Dependent Industrialization', American Political Science Association, 77, 569-87.

Eisinger, Peter K. (1988), The rise of the entrepreneurial state: State and local economic development policy in the United States (Madison: The University of Wisconsin Press).

Encarnation, Dennis J. and Louis T. Wells, Jr. (1986), 'Competitive strategies in global industries: A view from host governments', in Michael E. Porter (ed.), Competition in Global Industries (Boston, MA: Harvard Business Press), 267-90. 
Evans, P. (1995), Embedded autonomy: states and industrial transformation (Princeton, NJ: Princeton University Press).

Evans, P. (1997) 'The eclipse of the state? Reflections on stateness in an era of globalization', World Politics 50: 62-87

Forshaw, Stephen, (2011), 'Statement of Clarification - Temasek's share of Singapore economy possibly around 10\%'. published on 16 Aug 2011: http://www.temasek.com.sg/mediacentre/medialetters?detailid=8258

Freeman, John R. (1982), 'State Entrepreneurship and Dependent Development', American Journal of Political Science, 26, 90-112.

Gray, Cheryl Williamson, Lane, Tracey, and Varoudakis, Aristomène (2007), Fiscal Policy and Economic Growth: Lessons for Eastern Europe and Central Asia (Washington, DC: The World Bank).

Gross, Denis, (2010), 'Spotlight on Singapore: a sustainable city'. Cleantech magazine, May 2010 (http://www.cleantechinvestor.com/portal/spotlight/5571-spotlight-onsingapore-a-sustainable-city.html)

Hakim, C. (1982), Secondary Analysis in Social Research: A Guide to Data Sources and Methods with Examples (London: Allen \& Unwin).

Hall, Tim and Hubbard, Phil (1996), 'The entrepreneurial city: new urban politics, new urban geographies?', Progress in Human Geography, 20, 153-74.

Haque, M. Shamsul (2004), 'Governance and Bureaucracy in Singapore: Contemporary Reforms and Implications', International Political Science Review, 25, 227-40.

Harvey, David (1989), 'From Managerialism to Entrepreneurialism: The Transformation in Urban Governance in Late Capitalism', Geografiska Annaler. Series B, Human Geography, 71, 3-17.

Harvey, William S (2011), 'Strategies for conducting elite interviews', Qualitative Research, 11, 431-41.

Hee-Yeon, Cho (2000), 'The structure of the South Korean developmental regime and its transformation - statist mobilization and authoritarian integration in the anticommunist regimentation', Inter-Asia Cultural Studies, 1, 408-26.

Howells, Jeremy (1989), 'Externalisation and the Formation of New Industrial Operations: A Neglected Dimension in the Dynamics of Industrial Location', Area, 21 (3), 289-99.

Jessop, Bob (1990), State theory: Putting the capitalist state in its place (Pennsylvania: Pennsylvania State University Press).

Jessop, Bob and Sum, Ngai-Ling (2000), 'An Entrepreneurial City in Action: Hong Kong's Emerging Strategies in and for (Inter)Urban Competition', Urban Studies 37, 2287313.

Johnson, Chalmers A. (1982), MITI and the Japanese miracle : the growth of industrial policy, 1925-1975 (Stanford, Calif: Stanford University Press).

--- (1989), 'South Korean democratization: the role of economic development', The Pacific Review, 2, 1-10.

Kalinowski, Thomas (2015), 'Crisis management and the diversity of capitalism: fiscal stimulus packages and the East Asian (neo-)developmental state', Economy and Society 44, 244-70.

Kim, Eun Mee (1993), 'Contradictions and Limits of a Developmental State: With Illustrations from the South Korean Case', Social Problems, 40, 228-49.

Lan, Chao-Wei (2001), 'Singapore's Export Promotion Strategy And Economic Growth (1965-84)(http://www.bartlett.ucl.ac.uk/dpu/latest/publications/dpu-workingpapers/wp116.pdf). 
Larson, James F. and Park, Jaemin (2014), 'From developmental to network state: Government restructuring and ICT-led innovation in Korea', Telecommunications Policy, 38 (4), 344-59.

Lee, Kuan Yew (2000), From Third World To First: The Singapore Story 1965-2000 (Singapore: Times Editions).

Levi-Faur, David (2005), 'The global diffusion of regulatory capitalism', The ANNALS of the American Academy of Political and Social Science, 598, 12-32.

Low, Linda (2001), 'The Singapore developmental state in the new economy and polity', The Pacific Review, 14, 411-41.

--- (2005), 'Entrepreneurship Development in Ireland and Singapore', Journal of the Asia Pacific Economy 10, 116-38.

Majone, Giandomenico (1989), Evidence, Argument, and Persuasion in the Policy Process (New Haven and London: Yale University Press).

Mattessich, Paul W. and Monsey, Barbara R. (1992), 'Collaboration: What Makes It Work', (ERIC: https://eric.ed.gov/?id=ED390758).

Mazzucato, Mariana (2013), The Entrepreneurial State: debunking public vs. private sector myths (London: Anthem Press).

MEWR, Singapore, (2015), 'Our organisation history'. Official website of MEWR, Last updated on 02 Apr 2015 <http://www.mewr.gov.sg/about-us/our-organisation/history>

Miao, J. T. and Hall, P. (2013), 'Optical illusion? The growth and development of the Optics Valley of China', Environment and Planning C: Government and Policy, 31.

Miao, J. T. (2018), 'Parallelism and evolution in transnational policy transfer networks: the case of Sino-Singapore Suzhou Industrial Park (SIP)', Regional Studies, (https://doi.org/10.1080/00343404.2017.1418979).

MND, Singapore, (2015), 'Introduction'. Official website of the Ministry of National Development (MND), Last Updated on 28 September 2015 (http://app.mnd.gov.sg/AboutUs/Introduction.aspx)

National Library Board, Singapore, (2010), 'Jurong Town Corporation is established'. (http://eresources.nlb.gov.sg/history/events/9206cd21-7c6f-44fa-bd8d-c46e15cbbee3)

Nettl, J.P. (1968) 'The state as a comceptual variable', World Politics 20: 559-592

Ng, Marcus (2012), 'Liveable \& Sustainable Cities - Integrated Urban Solutions ', World Cities Summit 2012 (Singapore: Centre for Liveable Cities and Urban Redevelopment Authority), 84.

Olds, Kris and Yeung, Henry (2004), 'Pathways to global city formation: a view from the developmental city-state of Singapore', Review of International Political Economy, 11, 489-521.

Öniş, Ziya (1991), 'Review: The Logic of the Developmental State', Comparative Politics, 24, 109-26.

Pasotti, Eleonora (2010), Political branding in cities: the decline of machine politics in Bogotá, Naples, and Chicago (Cambridge: Cambridge University Press).

Pereira, Alexius A. (2002), 'The Suzhou industrial park project (1994-2001): The failure of a development strategy', Asian Journal of Political Science, 10, 122-42.

--- (2004), 'State entrepreneurship and regional development: Singapore's industrial parks in Batam and Suzhou', Entrepreneurship \& Regional Development, 16 (March), 129-44.

Perry, M. and Yeoh, C. (2000), 'Asia's transborder industrialization and Singapore's overseas industrial parks', Regional Studies, 4, 199-206.

Phelps, N. A. (2004), 'Triangular diplomacy writ small: the political economy of the Indonesia-Malaysia-Singapore growth triangle', The Pacific Review, 17, 341-68. 
Phelps, Nicholas A. (2007), 'Gaining from Globalization? State Extraterritoriality and Domestic Economic Impacts-The Case of Singapore', Economic Geography, 83, 371-93.

Pollitt, Christopher (2000), 'Is the Emperor In His Underwear? An analysis of the impacts of public management reform', Public Management, 2, 181-200.

Pow, Choon Piew (2014), 'License to travel: Policy assemblage and the 'Singapore model", City, 18, 287-306.

Riain, Sean O (2000), 'The flexible developmental state: globalization, information technology and the "Celtic Tiger"', Politics and Society, 28, 157-93.

Robinson, Mark and White, Gordon (1998), The Democratic Developmental State: Political and Institutional Design (Oxford: Oxford University Press).

SCE, Singapore (2016), Our Reach. (http://www.sce.org.sg/our-reach.aspx, 02/01/2017).

Stubbs, Richard (2009), 'What ever happened to the East Asian Developmental State? The unfolding debate', The Pacific Review 22, 1-22.

Tan, Augustine H H (1999), 'Official Efforts To Attract FDI: Case Of Singapore's EDB', EWC/KDI Conference on Industrial Globalization In The 21 st Century (Korea), 1-22.

Tan, Chwee Huat (1995), Venturing Overseas: Singapore's External Wing (Singapore: McGraw-Hill).

Tay, Kelly and Soh, Andrea, (2015), '50 and beyond: Singapore's economic transformation'. The Business Times: Infographics, published on 11st August 2015 (http://www.businesstimes.com.sg/infographics/50-and-beyond-singapores-economictransformation)

Teece, David J., Pisano, Gary, and Shuen, Amy (1997), 'Dynamic capabilities and strategic management', Strategic Management Journal, 18, 509-33.

Temasek, Singapore, (2014), 'JTC and Temasek to Explore Merger of Four Subsidiaries'. Temasek website, published on 4th Sep 2014: (http://www.temasek.com.sg/mediacentre/newsreleases?detailid=22137)

The Economist (2013), 'The entrepreneurial state', (Aug 31st, 2013).

Thurbon, E. and Weiss, L. (2006), 'Investing in Openness: The Evolution of FDI Strategy in South Korea and Taiwan', New Political Economy, 11, 1-22.

Tilly, Charles (1990), Coercion, Capital, and European States, AD 990-1992 (Oxford: Blackwell).

Victor Nee, Sonja Opper, and Wong, Sonia (2007), 'Developmental State and Corporate Governance in China', Management and Organization Review, 3, 19-53.

Wade, Robert (1990), Governing the Market (Princeton, NJ: Princeton University Press).

Webb, Flemmich, (2012), 'Sustainable cities: innovative urban planning in Singapore'. The Guardian, (http://www.theguardian.com/sustainable-business/sustainable-citiesinnovative-urban-planning-singapore)

Wong, Lawrence (2007), 'Development Strategy: Designing Market \& Growth', (http://siteresources.worldbank.org/EDUCATION/Resources/278200$1121703274255 / 1439264-$

1242337549970/Economic_Development_Strategy_Lawrence_Wong_v3.pdf: World Bank).

Woo-Cummings, Meredith (1999), The Developmental State (New York: Cornell University Press).

Yeung, Henry Wai-chung (2016), Strategic Coupling: East Asian Industrial Transformation in the New Global Economy (Ithaca, US: Cornell University Press).

Yip, Leo, (2013), 'Smart Cities: government-corporate partnerships to create urban solutions for the 21st Century'. EBD Singapore: (https://www.edb.gov.sg/content/edb/en/resources/downloads/articles/smart-citiesgovernment-corporate-partnerships-to-create-urban-solutions.html) 
Yu, Tony F. (1997), 'Entrepreneurial state: the role of government in the economic development of the Asian newly industrialising economies', Development Policy Review, 15, 47-64.

Zhang, Jun (2012), 'From Hong Kong's Capitalist Fundamentals to Singapore's Authoritarian Governance: The Policy Mobility of Neo-liberalising Shenzhen, China', Urban Studies, 49, 2853-71. 